\title{
O nekim vidovima poimanja vjere u Hansa Ursa von Balthasara i Paula Tillicha
}

\author{
HrVoje KALEM* \\ • https://doi.org/10.31823/d.26.3.2 • \\ UDK: 27-284-05Balthasar, H. U. * 2-184-05Tillch, P. • Izvorni znanstveni rad \\ Primljeno: 16. travnja 2018. Prihvaćeno: 17. rujna 2018.
}

${ }^{*}$ Dr. sc. Hrvoje Kalem,

Katolički bogoslovni

fakultet u Đakovu

Sveučilišta J. J.

Strossmayera u Osijeku,

P. Preradovića 17,

31400 Đakovo,

Hrvatska, hrvojekalem@ gmail.com

Sažetak: Pitanju vjere može se pristupiti pod mnogim vidovima, no jedno je sigurno: pod svim tim vidovima vjera je ono što dodiruje našu egzistenciju. Neovisno o putu kojim idemo prema vjeri krucijalno je ne izgubiti iz vida vrh kojemu nastojimo stići. Članak ima za cilj ukazati na dva različita pristupa poimanju vjere koja nose svoje prednosti i nedostatke. U prvome dijelu clanak se bavi promišljanjima o vjeri velikoga švicarskoga katoličkoga teologa Hansa Ursa von Balthasara čije je polazište uvjerenje da objekt objave uz koji prianjamo mora imati konkretnu formu (Gestalt). U daljnjoj analizi donose se neki temeljni vidovi razumijevanje vjere u promišljanjima toga teologa. Drugi dio članka bavi se razumijevanjem vjere/religije njemačko-američkoga protestantskoga teologa Paula Tillicha. Metodološki pristup poimanju vjere kod njega je posve oprečan Balthasarovome, ali otkriva i neke prednosti, kao isticanje važnosti situacije u kojoj naslovnici kršćanske poruke prianjaju uz Božju objavu te sam metodološki pristup poimanja vjere koji je prijemčiviji za one koji nemaju odredeno vjersko i teološko znanje i koji su jednostavno u potrazi za Bogom, na što upućuju zaključna zapažanja.

Ključne riječi: Balthasar, Tillich, vjera/religija, Gestalt, svjedočanstvo, središte i objekt vjere, iskustvo, situacija, apsolutno, kranja zaokupljenost.

\section{Uvod}

Hans Urs von Balthasar i Paul Tillich pripadaju teološkim velikanima XX. stoljeća, na čijim se djelima i refleksijama 
nadahnjujemo i u XXI. stoljeću. Zajednički cilj te dvojice teoloških giganata bio je učiniti razumljivom kršćansku poruku ljudima današnjice. $U$ tom pothvatu, baveći se širokim dijapazonom teoloških tema, Balthasar i Tillich služili su se različitim metodološkim polazištima. Jedna od tema kojoj su posvetili značajnu pozornost jest i vjera.

Promišljanje o vjeri velika je teološka tema ili bi to trebala biti u svakom razdoblju teološke djelatnosti. Čini nam se da je vjera ipak ponekada - bilo kao koncept, bilo kao, usuđujemo se reći, temeljna i najdublja dimenzija ljudske egzistencije - bila kontekst, i to nerijetko dalek i apstraktan, koji se podrazumijevao za bilo kakvu teološku elaboraciju. U vrijeme manualistike nije se posvećivala gotovo nikakva pozornost egzistencijalnoj dimenziji vjere. Razdoblje prosvjetiteljstva u kojem, među ostalim, dolazi do razdvajanja vjere i razuma, te razdoblje moderne i osobito postmoderne, u kojem svanjuje specifična vrsta potrebe za vjerom (likvidna vjera, vjerovanje bez pripadanja, individualizacija vjerovanja i relativizacija pripadanja) pomalo nas je ponovno, nakon skolastičkoga razdoblja, natjerao na sustavna promišljanja o vjeri, kada vjera ponovno postaje ne samo kon-tekst nego i tekst o kojem se raspravlja i teološki promišlja na više ili manje sustavan način.

Naše vrijeme obilježeno je svakom vrstom pluralizma, koje s modernom dostiže svoj vrhunac. Taj pluralizam nije zaobišao ni teologiju ni pristup teološkom promišljanju, a onda ni metode u teologiji. Riječ je jednostavno o različitosti teoloških oblika. Teološki pluralizam možemo promatrati kao posljedicu ljudskoga spoznavanja koje polazi iz više aspekata i iz posve različitih kutova gledanja na određenu stvarnost. ${ }^{1}$ Možda dva najpoznatija, a u isto vrijeme po metodološkom proizlaženju različita teološka oblika unutar katoličke teologije jesu Rahnerova antropocentrična i Balthasarova teocentrična teologija. Pogotovo u protestantskoj teologiji postoje različiti teološki oblici. Dovoljno je pomisliti samo na Barthovu dijalektičku teologiju, kojoj sučelice stoji Tillichova teologija korelacije s istoimenom metodom.

I pitanju vjere može se pristupiti iz različitih teoloških polazišta i metoda. Balthasarovo je polazište u promišljanju o vjeri teocentrično, odnosno njegovo je polazište odozgo, od objekta vjere i u tom smislu bio bi bliži Karlu Barthu na protestantskoj strani, dok je polazište Paula Tillicha posve antropološko i na katoličkoj strani bio bi bliži Rahnerovu antropocentričnom načinu promišljanja.

Tillich u svome razumijevanju vjere polazi od čovjeka koji postavlja pitanja, a odgovore na ta pitanja nudi mu teologija, koja pak svoje odgovore crpi iz objave. Za Tillicha objava je datost koja postoji i koju se kao takvu prihvaća, ali se u odgovoru na nju polazi od onoga tko treba dati taj odgovor, dakle od čovjeka i njegova traga-

${ }^{1}$ Usp. P. CODA, Teo-logia, Roma, ${ }^{2} 2009 ., 332$ s. 
nja. Balthasar pak polazi od Boga koji govori, naglasak je na objavi i opažanju objave pod konkretnom formom. On smatra da nije potrebno dati golem prostor našoj subjektivnoj potrazi za duhovnim smislom egzistencije, u krajnjoj liniji za Bogom, kad nam je sam Bog govorio.

Nalazimo se pred dvama različitim i posve oprečnim pristupima jednoj te istoj, važnoj i, nadasve, kod obojice autora egzistencijalno shvaćenoj temi. Usuđujemo se ovdje ustvrditi da vjera i egzistencija nisu dvije antropološke forme, nego jedna antropološka forma. Naglasak ovdje stavljamo na antropološku dimenziju (pretpostavljajući božanski sadržaj vjere) jer je čovjek jedini naslovnik objave i samo je on sposoban dati odgovor na taj Božji govor ${ }^{2}$. Jedino je čovjek sposoban za recepciju Gestalta koji se priopćava. Dakle, polazeći od objave kao priopćavanja forme (Gestalt), bitna je stvarnost čovjekove recepcije objave. Ono što na određeni način determinira čovjeka kao naslovnika objave jest njegova kulturna, jezična, kontekstualna i svaka druga uvjetovanost. Objavljujući se čovjeku, Bog računa sa svime onim što čovjek jest u svojoj ontološkoj i povijesnoj strukturi. Bog uzima u obzir njegov jezik, kulturu, povijest i slobodu koji postaju locus theologicus u kojem se, očitujući se, Bog ne odriče svoje skrivenosti. ${ }^{3}$ Ukratko, čovjek kao naslovnik objave nije puki pasivni promatrač prodiranja Božje slave i priopćavanja Gestalta, nego je zahvaćen tim događajem na koji je pozvan dati odgovor.

\section{Balthasarov kristološki pristup vjeri}

Balthasarov je pristup razumijevanju vjere kristološki, no da bi došao do središta toga sadržaja, odnosno do objektivizacije forme (Gestalta) koja je Isus iz Nazareta $^{4}$, potrebno je prijeći dug put. Kako bi došao do objektivnoga središta vjere, Balthasar najprije analizira povezanost vjere (pistis) i znanja $(\text { gnosis })^{5}$, i to dokazi-

\footnotetext{
${ }^{2}$ Usp. Katekizam Katoličke Crkve, Zagreb, 1994., br. 357.

${ }^{3}$ Usp. E. SALMANN, Presenza di spirito. Il cristianesimo come stile di pensiero e di vita, Assisi, 2011. 154-155.

${ }^{4}$ Usp. R. FISICHELLA, Balthasar, Hans Urs von, u: R. LATOURELLE, R. FISICHELLA (ur.), Dizionario di teologia fondamentale, Assisi, 1990., 97-103., ovdje 102. Gestalt je ono što izražava apsolutno te objavljuje apsolutno polazeći od sebe, no ostajući u sebi i u dubini koju izražava. Dobro zamjećuje Fisichella da Gestalt u Balthasara ima različitu upotrebu i kreće se u rasponu od fenomenološkoga prema metafizičkom vidu. Usp. ISTI, Uvod u fundamentalnu teologiju, Zagreb, 2015., 125. bilj. 39.

${ }^{5}$ Povezanost vjere i znanja važna nam je jer pokazuje kako u jedinstvu filozofije i teologije koje imaju zajednički formalni objekt Božja objava ne može biti drugo doli rješenje cijele čovjekove filozofsko-mitološke problematike koja se događa upravo u svjetlu Božje objave. To jedinstvo filozofije i teologije uvjetovano je time što u promišljanjima filozofa ne mogu postojati dvije konačne istine: jedna o svijetu, druga o čovjeku te jednako tako ne mogu postojati dva čovjekova krajnja stava na-
} 
ma iz Svetoga pisma i otačke teologije, oslanjajući se osobito na teologiju velikih aleksandrinaca. ${ }^{6}$

Polazeći od novozavjetnih interpretacija, kršćansku egzistenciju pokušalo se razumjeti pojmom vjere, tako da je, osobito u pavlovskom i ivanovskom korpusu, biti kršćanin identično biti vjernik. Pretpostavka takve identifikacije nalazi se u tome da se vjera ne sastoji samo od subjektivnoga čina (fides qua) nego i od sadržaja kojemu je taj čin usmjeren (fides quae). Čin vjere nije tek jedan pored mnogih drugih, nego ga se mora razumjeti kao cjelovito ponašanje kojim čovjek odgovara Božjoj objavi, odnosno kao cjelovit i konačan čovjekov stav pred Bogom. Time su se izbjegla dva ekstrema: prvi, da se vjeru interpretira kao kraj svake logike, gdje bi se doslovno shvatilo credo quai apsurdum est i drugi, tumačenje vjere posredstvom čisto prirodnih i unutarsvjetskih kategorija razumijevanja. ${ }^{7}$

Bog kao temelj svakoga bića objavljuje se u povijesti, u vremenu i prostoru. Takva kršćanska forma objave može se, prema Balthasaru, čitati na dva načina. Prvi način odnosi se na sveukupnost povijesnih znakova i načina Božjega pojavljivanja: izabranje, savez, vodstvo naroda preko sudaca, kraljeva itd. te, konačno, Krist kao onaj koji sve to ispunja u preobilju. Sami znakovi očituju to na što upućuju i zato zahtijevaju vjeru. Nasuprot spomenutim znakovima koji imaju snagu svjedočenja Božje objaviteljske prisutnosti (»Ako ne vjerujete u mene vjerujte barem u dje-

spram konačne stvarnosti. Usp. H. U. von BALTHASAR, Gloria: una estetica teologica. La percezione della forma, I, Milano, ${ }^{2} 2012$. (= Gloria, I), 130-132. O odnosu teologije i filozofije u Balthasara vidi: I. RAGUŽ, Teologija i filozofija kao sluškinje. Hans Urs von Balthasar o odnosu teologije i filozofije, u: ISTI, Teološki fragmenti III., Đakovo, 2017., 11-27. Jednaku tezu o odnosu filozofije i teologije zastupa i Paul Tillich koji nasuprot Pascalu tvrdi kako ne mogu postojati dva apsoluta: Bog Abrahamov, Izakov i Jakovljev i Bog filozofa, odnosno kako je eksplicitni objekt teologije ono što je implicitna pretpostavka cijeloga spoznavanja, pa i filozofije. Usp. P. TILLICH, Teologija kulture, Rijeka - Sarajevo, 2009., 26.; ISTI, L'era protestante, Torino, 1972., 67-68.

${ }^{6}$ Usp. H. U. von BALTHASAR, Gloria, I, 122-123. Za Klementa Aleksandrijskoga savršen kršćanin jest gnostik (ne u smislu heretika), koji nutarnje razumije svoju vjeru, u evanđeoskom smislu, (zahvaljujući svjetlu vjere). Razlika je između jednostavnoga vjernika i vjernika gnostika u tome što se prvi odnosi posve izvanjski prema sadržaju vjere i zaustavlja se na čisto autoritativnoj vjeri koja je prije svega posluh crkvenom navještaju, dok se vjernik gnostik trudi unutarnje prisvojiti ono što vjeruje te dalje razvija sadržaj vjere. Osobito je uočljiva Balthasarova analitička i interpretativna posvećenost tekstovima Ivanova evanđelja u kojima je vidljiva unutarnje neodvojiva i uska isprepletenost vjere i znanja kao npr. »Sve ako meni i ne vjerujete, djelima vjerujte pa uvidite i upoznajte da je Otac u meni i ja u Ocu « (Iv 16,38) ili »Sada znamo da sve znaš i ne treba da te tko pita. Stoga vjerujemo da si izišao od Boga « (Iv 16,30). U tom procesu kršćanin ne raste izvan navještaja Crkve, nego upravo u navještaju Crkve nalazi logos koji se objavljuje i koji prosvjetljuje na uvijek jasan način. Usp. isto, 120-122.

${ }^{7}$ Usp. isto, 117.128. Balthasar je, vjeran dvostrukoj dimenziji vjere fides qua i fides quae, podijelio prvi svezak svoga djela Gloria u dva dijela: subjektivna očiglednost i objektivna očiglednost. 
la koja ja činim « (Iv 10, 38)) Balthasar posvećuje pozornost formalnom objektu vjere, tj. vječnoj Božjoj istini, onoj kakav je Bog u samome sebi te se takvim svjedoči u objavi. Ta vječna istina jest unutrašnjost apsolutnoga bića, misterij njegova života i njegove ljubavi koja nam je dana u formi (Gestalt) Isusa Krista. Posebnost vidljive forme nije u tome da kao znak vjerodostojno upućuje na nevidljivi misterij i njegovu dubinu, nego je forma vidljiva po ljepoti koja iz nje isijava, ona je pojavak samoga misterija, objavljuje ga, dok ga u isto vrijeme skriva i otkriva. U formi je nemoguće odvojiti ono izvanjsko i unutarnje jer sadržaj ne leži iza forme, nego $u$ njoj. Onaj tko ne uspijeva vidjeti formu ne može obuhvatiti ni njezin sadržaj. ${ }^{8}$ Isus ne susreće jednostavno oblik Božje objave (savez, izabranje i sl.) koji bi trebao naviještati kao drugi proroci, nego, ako dolazi od Oca i vraća se Ocu, on je sam forma Božje objave. U tome je riječ o utemeljenju objekta objave polazeći od Boga, a ne od čovjeka, kako je slučaj u nekim drugim teologijama. Riječ je o odnosu koji možemo nazvati objektivnim odnosom između temelja i forme te sadržaja i forme. ${ }^{9}$

\subsection{NEKI ELEMENTI FORME VJERE}

Prethodni elementi pružaju nam dovoljno argumenata da barem inicijalno odredimo Balthasarovo poimanje kršćanske vjere kao percepciju i gledanje forme koja se pojavljuje u povijesnom trenutku u osobi Isusa Krista kao izrazu samoga Boga; odnosno kršćanska vjera jest, u svome subjektivnom polu, percepcija (Wahrnehmung) forme (Gestalt). ${ }^{10}$ Kršćanska misao bila je oduvijek svjesna činjenice da je Isus Krist središnja forma objave, polazeći od koje se razjašnjavaju i ujedinjuju svi ostali momenti spasenjske objave, a svjetlo na tu formu ne pada odozgo ili izvana, nego probija iznutra.

Jedan od elemenata forme vjere jest Božje svjedočanstvo u nama, ${ }^{11}$ o kojemu Balthasar promišlja polazeći od Prve Ivanove poslanice: »Ako primamo svjedočanstvo ljudi, svjedočanstvo je Božje veće. Jer ovo je svjedočanstvo Božje, kojim je svjedočio za Sina svoga: Tko vjeruje u Sina Božjega, ima to svjedočanstvo Božje u sebi.« (1 Iv 5, 9-10) Kršćanska vjera može biti shvaćena samo kao naš odgovor na to unutarnje Božje svjedočanstvo o samome sebi. Božja inicijativa biva tako sačuvana i vjera ostaje dar. To Balthasar dokazuje nizom primjera iz Svetoga pisma: »Isus reče satniku: 'Idi neka ti bude kako si vjerovao!' I ozdravi sluga u taj čas « (Mt 8, 13), ili: »Hra-

\footnotetext{
${ }^{8}$ Usp. isto, 133-139.

${ }^{9}$ Usp. isto, $297 \mathrm{~s}$.

${ }^{10}$ Usp. R. GIBELLINI, La teologia del XX secolo, Brescia, ${ }^{6} 2007 ., 258$.

${ }^{11}$ Usp. H. U. von BALTHASAR, Gloria, I, 142-157. O konceptu svjedočanstva s osvrtom na Balthasarovo tumačenje toga koncepta vidi u: P. MARTINELLI, La testimonianza. Verità di Dio e libertà dell'uomo, Milano, 2002.
} 
bro, kćeri, vjera te tvoja spasila.« (Mt 9, 22) U tim primjerima Isus se pokazuje kao onaj koji može i kao onaj koji ima moć. U konačnici to implicira da Isus može živjeti za mene, on mi priopćava Božju moć i snagu. ${ }^{12}$ Posve je razumljivo reći da nam Bog u objavi svjedoči sama sebe jer ne bismo mogli ni trebali vjerovati u jedno povijesno biće zbog Božjega svjedočanstva ako to ne bismo vjerovali snagom Božjega bića koje svjedoči samoga sebe, što nama postaje jasno po unutarnjem svjetlu vjere. Sin Božji koji u povijesti svjedoči Boga i prima Božje svjedočanstvo uvjerava nas samo zato što mi imamo u sebi Božje svjedočanstvo. ${ }^{13}$

Drugi element forme vjere jest svjedočanstvo Boga u povijesti. ${ }^{14}$ Najeminentnije Božje svjedočanstvo u povijesti jest ono u formi Krista nazočnoga u svijetu. Odlučujući trenutak sastoji se u ćinjenici da ta forma predstavlja samu sebe kao objavu Božje nutarnje dubine i to snagom same svoje biti po savršenoj recipročnosti između svjedočenja Sina za Oca i Oca za Sina. Na taj način Krist može reći: »Tko u mene vjeruje, ne vjeruje u mene, nego u onoga koji me posla; i tko vidi mene, vidi onoga koji me posla.« (Iv 12, 44-45) To svjedočanstvo nam je bitno jer pokazuje da nije čovjekova ljubav prema Bogu stvorila sliku Boga kako bi ga mogla bolje ljubiti u toj slici i preko nje, nego slika predstavlja samu sebe kao nešto što se ne može pronaći polazeći od čovjeka i koju je moguće razumjeti samo kao pronađenu Božju ljubav i kao takvoj joj vjerovati. U tom kontekstu Balthasar je uvjeren kako je središnje pitanje fundamentalne teologije pitanje viđenja/opažanja forme, odnosno na koji se način Božja objava čini prisutnom ljudima i kako ju se opaža. Zahvaljujući nauku o očima vjere koji razvija Pierre Roussoue, Balthasar podcrtava kako je ohrabrujuće da u vjeri ima nešto za vidjeti/opaziti i odatle dolazi do zaključka da je kršćanska vjera sposobnost opažanja onoga što nam Bog očituje, odnosno da ono što nam Bog pokazuje može biti viđeno samo vjerom. ${ }^{15}$

U svojim promišljanjima o vjeri Balthasar slijedi posve obratnu perspektivu od modernističke koja predstavlja pretjerani subjektivizam. Za njega je dispozicija unutarnjega svjetla vjere određena prema objektivnoj formi objave, ${ }^{16}$ a ne prema su-

\footnotetext{
${ }^{12}$ Usp. H. U. von BALTHASAR, Gloria, I, 551.

${ }^{13}$ Usp. isto, 149 s.

${ }^{14}$ Usp. isto, 157-175.

${ }^{15}$ Usp. isto, 160-162. Apologetika XIX. stoljeća nije uspjela uvidjeti formu (Gestalt) koju Bog stavlja pred nas na nedvosmislen način te se posve odalečila od temeljnoga pitanja: na koji se način Božja objava čini prisutnom ljudima i kako ju se opaža. Nemoguće je Krista smatrati znakom među drugim znakovima. Balthasar se naslanja na Pierra Roussouea i kritizira njegov nauk o očima vjere jer i kod njega Krist ostaje samo znak, a ne forma kako bi Balthasar htio. Važno je napomenuti i da u promišljanjima o očima vjere u pozadini stoji misao Tome Akvinskoga i Mauricea Blondela i njegova dinamička otvorenost duha punini bitka. Usp. isto, 161.
}

${ }^{16}$ Usp. isto, 163. 
bjektu i njegovoj potrazi. Tako bismo mogli reći da je za njega vjera više Božje djelo nego naše jer vjera opaža božansko svjetlo (usp. 2 Kor 4, 6) i participira na samoobjavi Božjega života i Božjega unutarnjega svjetla. Takva postavka vjere obvezuje nas da napustimo svaku potpuno izvanjsku mapu vjere. ${ }^{17}$ Subjektivna očiglednost vjere određena je objektivnom očiglednošću povijesne figure Isusa Krista, njegovom formom, njegovim Gestaltom; on je mjera svake mjere i mjera koja nije ničim mjerena. ${ }^{18}$ Objektivna očiglednost kao ono što uvijek iznenađuje te kao ona koja nije određena subjektivno uvijek prethodi i određuje subjektivnu očiglednost, a nikada suprotno. ${ }^{19}$ Snaga sposobnosti aktivne vjere ne nalazi se primarno u samom vjerniku, nego u Bogu koji, objavljujući se, nastanjuje se u vjerniku dajući mu mogućnost participacije na vlastitom svjetlu i vlastitom činu. Vjernik ima iskustvo te čudesne stvarnosti upravo u susretu s formom vjere u povijesti u kojoj Bog postaje njegov Bog-nasuprot. ${ }^{20}$ Isus Krist je ta forma u kojoj Bog postaje čovjeku Bog-nasuprot. Ljudski duh ne može u sebe primiti nešto što mu je posve strano jer bi ga to vodilo dezintegraciji, zato je jasno kako je ta forma već posvjedočena u nama. Tako Isus nije tek neki puki znak, nego forma, i to determinirajuća forma Boga, tj. ona koja određuje Boga u svijetu. On je forma koja se razlikuje od estetskih slika i oblika svijeta zbog činjenice da je on arhetipska forma. On je pralik, praforma koja ima život u sebi. ${ }^{21}$

\subsection{ISUS KRIST - SREDIŠTE FORME OBJAVE}

Sljedeće pitanje koje je nužno razjasniti u takvom poimanju vjere jest pitanje razumijevanja forme. U odgovoru na to pitanje Balthasar polazi od forme čovjeka kojega volimo i koji nam je blizak. On ostaje za nas uvijek misterij, odnosno ostaje nedostižan našoj sposobnosti prodiranja u njega i ako zaista volimo tu osobu, ne ćemo željeti dokinuti njezin misterij. Ako to vrijedi za čovjeka, još više vrijedi za Boga objavitelja. No, unatoč tomu, mi možemo točno interpretirati konture te forme i razumjeti ono što ta forma želi izraziti jer nam je ona sama dala dovoljno da shva-

\footnotetext{
${ }^{17}$ Usp. M. P. GALLAGHER, Mappe della Fede. Dieci grandi esploratori cristiani, Milano, 2011., 71.

${ }^{18}$ Usp. H. U. von BALTHASAR, Gloria, I, 449s. Balthasar je smatrao kako je Kant istinski izvor subjektivizma koji se prema Balthasaru nazirao i u Rahnera. Zbog toga Balthasar više cijeni Goethea koji je zaštitio našu sposobnost divljenja i prepoznavanja ljepote. Usp. M. P. GALLAGHER, Mappe della Fede, 70.

${ }^{19}$ Usp. M. HODŽIĆ, La genesi della fede. La formazione della coscienza credente tra essere riconosciuto ed essere riconoscente, Roma, 2009., 49.

${ }^{20}$ Usp. H. U. von BALTHASAR, Gloria, I, 164.

${ }^{21}$ Usp. isto, 167.
} 
timo te pozvala ljude da se njome mjere kako bi ju razumjeli. ${ }^{22} \mathrm{Ta}$ forma ponudila se svojim samopriopćavanjem, $\gg$ izručila se u prljave ruke $l j u d i \ll,{ }^{23}$ izložila se ljudskom pogledu i dio je njezine temeljne zadaće očitovati i obznaniti Boga. Za percepciju te forme potreban je jedan otmjeniji pogled od onoga za percepciju bića. Povijest kršćanstva koje je znalo opaziti/percipirati formu naravnog svijeta bila je opskrbljena iznimnim okom, oblikovanim tako da svjetlom milosti može opaziti istinu objave kao formu i interpretirati je. ${ }^{24} \mathrm{Način} \mathrm{razumijevanja} \mathrm{te} \mathrm{forme}$ postaje jasniji ako se složimo s Balthasarom da unutarnje svjetlo očiju vjere postaje jedno s vanjskim svjetlom koje odsijeva u Kristu. Upravo zato što čežnja u čovjeku i traženje Boga dolaze svomu miru u formi objave Sina ili kako to Balthasar izvrsno sintetizira: »pred preobilnim svjetlom koje se izlijeva iz ove forme, svaka subjektivna potraga odlaže oružje (...) Mir je tamo gdje se Bog očituje u čovjeku Kristu i predanje je nadiđeno u prihvaćanju. ${ }^{25}$ Vjernik dakle zna da je prihvaćen zajedno sa svojim odgovorom vjere; odnosno u trenutku u kojemu počinje gledati očima vjere vjernik postaje duboko svjestan da ga je Bog već vidio. Vjernik tako pronalazi sebe, zadobiva sebe u objektu svoje vjere te pronalazi vlastito svjetlo vjere u Kristovu svjetlu kao prauzoru koji jedini čini vjeru mogućom. Time Balthasar pokazuje kako svjetlo vjere odsijeva polazeći samo od objekta vjere i kako je to svjetlo svjedočanstvo kojim Bog u Isusu Kristu daje svjedočanstvo o samome sebi. ${ }^{26}$

Forma Isusa Krista ne stoji odvojena od vjernikova pogleda. Ona je neodvojivo umetnuta u cjelinu istine koju sačinjavaju Isusovo propovijedanje i događaji te $\mathrm{u}$ cjelinu posredničkih crkvenih istina koje su njime uvjetovane i koje upućuju na njega. Forma Isusa opaža se samo u tim kontekstima koji su neodvojivi od njega ako se nalaze u vrlo uskom ontološkom odnosu s formom koju se opaža. ${ }^{27}$

\footnotetext{
${ }^{22}$ Usp. isto, 172. U tom smislu, imajući u vidu formu (Gestalt) koja nam se tako vidljivo i jasno nudi, moguće je reći kako se prianjanje vjere uz nevidljive misterije zahtijeva samo u mjeri u kojoj su ti misteriji u organskom odnosu s objavljenom formom te tako primaju mjesto neposredne duhovne vidljivosti. To nam omogućuje shvatiti Presveto Trojstvo, preobrazbu, uskrsnuće tijela i samu euharistiju. Balthasar ide i korak dalje te ističe da je i u spoznaji vjere koja u sebi ne kontemplira Božje misterije, moguća autentična percepcija forme. To se zaključuje polazeći od koncepta prae-ambula fidei, gdje to vremensko prae treba shvatiti dinamički, kao inicijalno razumijevanje forme objave koju čovjek ne može ne opaziti. Usp. isto, 174.

${ }^{23}$ E. SALMANN, Presenza di spirito, 281.

${ }^{24}$ Usp. H. U. von BALTHASAR, Gloria, I, 20.

${ }^{25}$ Isto, 175.

${ }^{26}$ Usp. isto, 175-177. Ovdje je bitno istaknuti da je, prema Balthasaru, darivanje sebe u vjeri i njezinoj životnoj konkretnosti ukorijenjeno u ljubavi. Sve praktične i teoretske poteškoće vjere rješavaju se kad se prispije dubokom planu ljubavi.

${ }^{27}$ Usp. isto, $182 \mathrm{~s}$.
} 
Središnja forma očiglednosti o kojoj ovise sve druge jest percepcija objektivne forme Boga u Isusu Kristu. »U ovoj formi sjaji objektivna Božja slava, ona je definitivni kabod, poslana i pozvana svojom slavom prekriti tabernakul čitava stvaranja. $\ll^{28}$ Tako je jedini autentični motiv kršćanske vjere Božja objava, a posredništvo crkvenoga učiteljstva i vanjskih znakova vjerodostojnosti događa se samo kao uvjet. ${ }^{29}$

Izraz središte forme objave ne želi naznačiti jedan dio oko kojega bi bili potrebni drugi periferni dijelovi koji bi okruživali središte. Taj izraz odnosi se na ono po čemu forma prima povezanost i razumljivost u svojoj cjelini i zbog čega se sve partikularne dimenzije moraju odnositi prema toj formi kako bi bile shvatljive. Da je Krist to središte, ovisi o osobitom karakteru kršćanske religije u kojoj je Krist jedinorođeni Sin Očev i sve što on utemeljuje ima smisla samo po njemu. Ono što je spetificum u Kristovoj formi može se očitovati samo polazeći od njega. Nijedna subjektivna datost kojom bi se objekt mogao opaziti ne utemeljuje objektivnu očiglednost. Krist nije ovisan ni o jednom subjektivnom uvjetu tako da ga takav subjektivan uvjet može zapriječiti da se učini apsolutno shvatljivim čovjeku. Balthasar naglašava da figura koju Krist oblikuje posjeduje u sebi istinu unutarnje očitosti na jednak način kao što je posjeduje neko umjetničko djelo ili matematički princip. ${ }^{30}$

Postajući čovjekom, Bog ne govori sebi, nego svijetu, a Krist je taj Božji govor upućen svima. Tako mi nismo zahvaćeni izvana, nego smo dodirnuti u vlastitoj naravi jer Bog u Kristu postaje nama u svemu jednak, osim u grijehu. Poslušnost je ključni stav kojim Balthasar objašnjava Božju sliku koja u Kristu za nas postaje konkretnom formom. On u poslušnosti od Oca prima poslanje, kod njega postoji savršena podudarnost ili identitet između poslanja i egzistencije. Upravo zbog poslušnosti kod Isusa nema hybrisa. Percepcija forme (Gestalt) ne dokida subjekt upravo zato što u Bogu postoji forma. Kada ne bi bilo forme u Bogu, onda ne bi moglo biti nikakve forme ni između Boga i čovjeka, a ako bi bilo tako, onda bi se dogodilo kao u mistikama izvan kršćanstva u kojima beskonačno apsorbira konačno. Samo kr-

\footnotetext{
${ }^{28}$ Isto, 187.

${ }^{29}$ Usp. isto, 194-195. Ako je Crkva primila obvezu navještaja, onda vjernik ne vjeruje $u$ Crkvu, nego prihvaća njezino autoritativno svjedočanstvo o Kristu kako bi vjerovao, oslanjajući se i na samo Kristovo svjedočanstvo. Crkva po svojim predstavnicima ne podčinjava nikoga sebi, nego Bogu kojemu se jedino usmjeruje čin vjere. Pod tim vidom govori se o credo Ecclesiam u Apostolskom vjerovanju, a ne pod vidom da bi Crkva bila subjekt kojoj je usmjeren čin vjere. U tom smislu treba čitati pojedine članke vjere preko kojih vjera može doći do osobe Isusa Krista i preko njega do trojstvenoga i osobnoga Boga. Vjernik ne prianja uz prijedloge vjere, nego uz ono što oni izražavaju, a to je uvijek živi Bog u Isusu Kristu. Tako je prema Balthasaru crkveni autoritet sredstvo, a crkveni život ima za cilj učiniti vidljivom formu (Gestalt) Sina i za one koji ne vjeruju. Usp. isto, 193-197.

${ }^{30}$ Usp. isto, 435-437.
} 
šćanstvo može objediniti dvije dimenzije jer očitovanje trojstvenoga Boga, prema Balthasaru, ne može se dogoditi osim u formi. ${ }^{31}$

Balthasar donosi četiri bitna elementa u kojima se može opaziti jedinstvena očiglednost forme Krista. Prvi je kontemplacija po kojoj se događa metamorfoza onoga koji kontemplira u kontempliranu sliku. Kroz tu kontemplaciju kontemplirani se utiskuje u nas i postaje kontemplacija za nas. Metamorfoza o kojoj govori Pavao: $\gg$ Ne suobličujte se ovomu svijetu, nego se preobrazujte obnavljanjem svoje pameti da mognete razabirati što je volja Božja, što li je dobro, Bogu milo, savršeno « (Rim 12,2), u prvom je redu prihvaćanje forme i prihvaćanje Krista u nama. Drugi element po kojem se opaža forma jest vlastita snaga forme koju Novi zavjet opisuje kao dynamis ili Duh. Treći smjer tiče se jedincatosti forme koja je neodvojivo vezana uz Stari zavjet i gledamo je kao jednu objavu u smislu obećanja i ispunjenja. Ta jedincatost forme apsolutno je jedinstvena u odnosu na sve druge religije. Četvrti element koji nam pomaže opaziti objektivnu očiglednost forme jest skrivenost forme. Riječ je o tome da Isus ne želi da se sazna za njegovo mesijanstvo, pa zapovijeda nečistim dusima da šute o njemu, od izliječenoga gubavca traži da ne govori nikome, odlazi na samotna mjesta itd. Tu skrivenost svoga mesijanizma Isus ne želi zbog sebe, nego kako bi omogućio da se njegova mesijanska obećanja ispune, ali ne na način kako to zamišljaju i tumače Židovi. Mnogo je teže jer nije riječ samo o njegovoj poruci nego i o njegovoj osobi. Zbog toga Isus skriva svoj mesijanizam, ali ga u isto vrijeme i objavljuje po liječenju bolesnih i drugim znakovima. ${ }^{32}$

U konačnici, formu Krista opažamo po posredovanju Svetoga pisma i Crkve, kao i po svim formama crkvene egzistencije koje se utiskuju u Kristovu formu (propovijedanje, liturgija, sakramenti, Crkva).

Kristova forma nije posvjedočena samo izvana nego i iznutra. Svjedočanstvo Kristove forme jest svjedočanstvo Boga o samome sebi, kako smo vidjeli. Prema sv. Ivanu evanđelistu četiri su tipa svjedočanstva. Prvo je ono koje Otac daje za Sina u njemu samome, u njegovim riječima i djelima; zatim svjedočanstvo Staroga zavjeta, Abrahama, Mojsija i proroka i Ivan Krstitelja. Treće je svjedočanstvo djela, tj. snage koju Otac daje Sinu nad kozmosom, nad vrhovništvima, nad anđelima, nad smrću, dio te moći čine i uskrsnuća koja Isus čini, kao i samo njegovo uskrsnuće. Četvrti tip svjedočanstva jest svjedočanstvo Duha Svetoga. Ta četiri tipa svjedočanstava nisu iste važnosti. Najviše je svjedočanstvo koje daje Otac. U Sinu se u prvom redu svjedoči Otac i obratno, Isusovo svjedočanstvo svjedoči Oca. Duh daje svjedočanstvo za Sina koji je živio na zemlji. To unutrašnje svjedočanstvo Oca za

\footnotetext{
${ }^{31}$ Usp. isto, 449-452.

${ }^{32}$ Usp. isto, 453-484.
} 
Sina i Sina za Oca daje autentičnost formi. Taj je primjer jedinstven jer je u njemu odnos između temelja i forme $\mathrm{u}$ isto vrijeme osoban. Otac daje autentičnost Sinovljevim riječima i djelima, njegovoj formi poniženja i poslušnosti kao autentični izraz božanske naravi jer samo Bog može autentično izraziti Boga. ${ }^{33}$

\subsection{ISKUSTVO VJERE}

Ako vjeru kod Balthasara shvatimo kao opažanje forme te imamo u vidu preobražavajuću snagu forme (Gestalt) čije svjetlo isijava iz nje same, onda je u tome implicitno sadržano uvjerenje da je vjera čin cijeloga čovjeka, u svim njegovim dimenzijama: voljnoj, spoznajnoj, afektivnoj, svjesnoj i podsvjesnoj. Vjera je susret cijeloga čovjeka s Bogom. Balthasar to izražava još snažnije: »Vjera, u punom kršćanskom smislu ne može biti drugo doli ovo: preobrazba čitava čovjeka u prostor odgovora na božanski sadržaj. $\ll{ }^{34}$ Upravo kategorija percepcije omogućuje Balthasaru da promatra vjeru kao čin koji se tiče cjelovite ljudske osobe, u svim njezinim dimenzijama jer percepcija smjera na cjelovitost, uključujući osjetilnost i druge dimenzije ljudskoga duha: volju, inteligenciju i sve što sačinjava ontološku strukturu osobe te omogućuje percepciju.

Kategorija percepcije/opažanja koja je ključna za vjeru i iskustvo vjere daje Balthasaru mogućnost vrlo širokoga poimanja vjere, ali, naravno, uvijek u povezanosti s objektom vjere, odnosno s formom (Gestalt) Isusa Krista. U takvoj percepciji forme iznimnu ulogu imaju ljudska osjetila jer samo preko njih čovjek cjelovito opaža i osjeća stvarnost svijeta i bitka, dakle i stvarnost objave, pa onda i vjere. Riječ je o stanovitom conversio ad phantasma koji je temelj razumijevanja Božanskoga sadržaja izraženoga u formi (Gestalt) Isusa Krista. Ovdje bismo željeli istaknuti da zahvaljujući upravo uključenosti osjetila, koja sačinjavaju konstitutivnu dimenziju ljudske osobe, čovjek može vjerovati quia apsurdum est. Po osjetilima - koja su dugo vremena bila zapostavljena dimenzija ljudske osobe u kontekstu vjere, možda zbog straha od romanticizma u vjeri - čovjek se može posve predati misteriju, a ništa kao misterij ne fascinira, ne dovodi do ushićenja i zanosa. Prema Balthasaru, središte čina susreta između Boga i čovjeka ostvaruje se tamo gdje ljudska profana osjetila, omogućavajući čin vjere, postaju duhovna osjetila te tako i vjera kao ljudski

\footnotetext{
${ }^{33}$ Usp. isto, 571-579. Razumijevanje forme objave u kojoj Otac svjedoči sama sebe pretpostavlja unutarnje priopćavanje. Kako bi se moglo opaziti Božju formu, potrebno je interiorizirati se u njoj, ući u njezin krug i njezinu zonu ižarivanja te doći u stanje u kojemu ona postaje očita u svome biti-u-sebi. Usp. isto, 582s.

${ }^{34}$ Isto, 204. Kurziv je naš.
} 
čin postaje osjetilna. Ovdje nije riječ jednostavno o osjetilima, nego o duhovnim osjetilima. ${ }^{35}$

To da je vjera egzistencijalna podrazumijeva važnu ulogu koncepta iskustva. Općenito gledano, možemo reći da u Balthasarovim promišljanjima iskustvo vjere označava da se objekt vjere nudi samo u mjeri u kojoj se cjelovit čovjek izručuje onomu što vjeruje. ${ }^{36}$

Biblijsko iskustvo Boga označeno je prije svega činjenicom da Bog koji prebiva u nedostupnu svjetlu dolazi u vidljivom obliku. On koji nema formu uzima formu u svijetu i u povijesti te ga se može susresti na posve ljudski način u formi ${ }^{37}$ koju je izabrao on sam. Opažanje Boga postoji samo (omogućeno po njegovoj milosti) ondje gdje on dolazi u svijet. Da mi postajemo dionici toga Božjega dolaska, događa se u procesu u kojem se uzvišenje čovjeka događa u sniženju Boga. Otac koji nema formu objavljuje su u formi i slavi Sina. Gledanje Oca u Sinu za čovjeka je neposredno gledanje. Kristološka forma jest forma susreta između Boga i čovjeka gdje Krist kao pravi i potpuni čovjek ima iskustvo onoga što je Bog i gdje u isto vrijeme Krist kao utjelovljeni Bog ima iskustvo onoga što je čovjek. Polazeći od toga arhetipskoga iskustva, ljudi su pozvani na takvo iskustvo. ${ }^{38}$ Arhetipsko iskustvo koje Isus ima o Ocu neka je vrsta nadvjere koja je jednaka Isusovu gledanju Oca. Iskustvo Boga koje imaju učenici nasljedovanje je koje se neodvojivo sastoji u vjeri u Krista i s Kristom u Boga. Iskustvo Boga koje pak ima Crkva jest sudjelovanje i nasljedovanje, po apostolskoj i crkvenoj kerigmi, toga arhetipskoga jedinstva vjere i gledanja koje su imali svjedoci. Mi dakle posredstvom svjedočenja svjedoka nasljedujemo njihovo arhetipsko iskustvo i cjelovitu strukturu njihova iskustva Krista u mjeri u kojoj nam je to vlastito. ${ }^{39}$

${ }^{35} \mathrm{O}$ tome više usp. H. U. von BALTHASAR, Gloria, I, 339-342. Bonaventura i drugi srednjovjekovni teolozi poput Alberta Velikoga slažu se da su duhovna osjetila činovi ljudskoga duha i volje u kontemplativnom razumijevanju Boga olakšani i usavršeni zahvaljujući trostrukom izlijevanju krjeposti i darova Duha Svetoga. Duhovna osjetila dakle ne čine neku drugu višu sposobnost pokraj tjelesnih osjetila. Usp. isto, 342-351.

${ }^{36}$ Usp. isto, 206-223.

${ }^{37}$ Oslanjajući se na Romana Guardinija i Gustava Siewertha, Balthasar tumači da forma nije samo nešto tjelesno nego označava i zakon proporcije, funkcionalni kontekst, formu razvoja, vrijednosnu figuru i sve je to i duhovno i materijalno. Dakle duhovna dimenzija ne dodaje se naknadno, nego je otpočetka konstitutivna za čovjeka. Usp. isto, 361-364.

${ }^{38}$ Usp. isto, 278-281.

${ }^{39}$ Usp. isto, 282. Ovdje se implicitno pojavljuje i tema prenošenja vjere koju Balthasar ne obrađuje, no o važnosti prenošenja vjere neka nam bude slobodno, među mnogima, uputiti i na: S. DIANICH, Comunicare il Vangelo. Ecclesiologia della parrocchia, u: Il Regno - Attualità 48(2003.), 419-425. 
Podrobnije pitanje Isusova iskustva vjere, odnosno problematiku pitanja fides Chri$s t i$, Balthasar je obradio na drugome mjestu. ${ }^{40}$

\section{Paul Tillich: vjera kao iskustvo apsolutnoga ${ }^{41}$}

\subsection{NARAV RELIGIJE}

Tillich u svome poimanju vjere/religije počinje od iskustva. Za njega je vjera iskustvo apsolutnoga. ${ }^{42}$ Ovdje je potrebno pojasniti kako u Tillichovu promišljanju o vjeri nema razlike između pojmova vjera i religija, kao npr. u promišljanjima Karla Bartha. Za Tillicha religija nije pokrivalo vjere, odnosno samo ono izvanjsko vjere. Religija kao i vjera znači biti zahvaćeni nekom vrhovnom, krajnjom instancom u odnosu na koju su sve druge preliminarne. Bilo bi pogrješno promatrati religiju samo kao sustav simbola, obreda i emocija usmjerenih prema nekom vrhovnom biću. Religija je stanje onoga tko je zahvaćen nečim bezuvjetnim, svetim i apsolut$\mathrm{nim}$. Kao posvemašnji odgovor osobe na ono što nazivamo sveto, religija je vjera. I u pojmu vjera i u pojmu religija naglasak je stavljen na vrhovni interes, krajnju zaokupljenost. ${ }^{43}$ Vjera, shvaćena kao iskustvo apsolutne vrijednosti, predstavlja vrlo široko značenje jer se, zahvaljujući vlastitoj slobodi, čovjek može odlučiti za Apsolutno, ali isto tako i za pogrješno apsolutno. Čovjekova vjera pokazuje se manjkavom ako je njegova egzistencija određena nečim što nije istinsko apsolutno. Dakle u vjeri, shvaćanoj kao iskustvo apsolutnoga, temeljno pitanje jest: što je apsolutno, krajnje i vrhovno za čovjeka. Ovdje već vidimo da je Tillichov metodološki pristup posve različit od Balthasarova. Kod Balthasara je ono krajnje, apsolutno, vrhovno (rečeno Tillichovim rječnikom) na početku; ono je ono objektivno na temelju čega čovjek zauzima stav i čime postaje zahvaćen, a kod Tillicha, koji subjektivno pristupa vjeri, čovjek je onaj koji se bori da ne izabere pogrješno apsolutno.

Već sada primjećujemo kako u Tillichovim promišljanjima o vjeri ne vidimo Gestalt, koji treba opaziti i uz koji treba prianjati te ga na kraju slijediti. U njegovim promišljanjima subjekt je taj koji određuje objekt, a nije subjekt određen objektom kao što je slučaj u Balthasarovim promišljanjima o vjeri. Apsolutno, krajnje, vrhov-

${ }^{40}$ O tome vidi: H. U. von BALTHASAR, Fides Christi, u: ISTI, Sponsa Verbi. Saggi Teologici 2, Milano, 2015., 31-61.

${ }^{41}$ Promišljanje o vjeri u Paula Tillicha koje donosimo ovdje, dio je naše objavljenje doktorske disertacije naslovljene La correlazione tra Vangelo, cultura e persona umana nella riflessione di Paul Tillich e Karol Wojtyta per un cristianesimo rilevante oggi, Roma, 2017.

${ }^{42}$ Usp. P. TILLICH, Dinamica della fede, Roma, 1967., $15 \mathrm{~s}$.

${ }^{43}$ Usp. isto, 15-17.; P. TILLICH, L'era protestante, 87.; D. TOLVAJČIĆ, Religija kao »ono što nas se bezuvjetno tiče «. Skica jednog mogućeg filozofijskog pristupa religiji, u: Bogoslovska smotra 84(2014.)2, 221-233.; E. VILANOVA, Storia della teologija cristiana, III, Roma, 1995., 538. 
no, sveto nema nikakvu konkretnu formu. Jedan od razloga svakako je i to što se Tillichovo poimanje objave može opisati krajnje neodređeno, kao erupcija bezuvjetnoga u svojoj bezuvjetnosti. ${ }^{44}$ Tako shvaćena objava ne daje nikakav konkretan oblik. O takvoj ne-formi objave ne postoji ni unutarnje svjedočanstvo Boga ni svjedočanstvo Boga u povijesti, kako Balthasar pokazuje na temelju ivanovskih spisa. ${ }^{45}$

I u Balthasara i u Tillicha vjera je čin cjelovitoga čovjeka, što uključuje sudjelovanje svih svjesnih i nesvjesnih elemenata ljudske osobe u činu vjere. Ti elementi konstituiraju središnji čin vjere. U čovjekovu ja konvergiraju i ujedinjuju se svi elementi njegova bića kao u jednom središtu i teže prema apsolutnomu. ${ }^{46}$

Vjera koja je življena kao iskustvo apsolutnoga pretpostavlja da sve druge stvarnosti postanu preliminarne i podložne apsolutnome. Zbog toga to apsolutno daje dubinu svim drugim čovjekovim zaokupljenostima i tako cijelome čovjeku i njegovim činovima. U čovjekovoj egzistenciji interes ili preokupacija za apsolutno jest odlučujuća jer je ono $\gg$ u odnosu sa svim drugim vidovima stvarnosti i ljudske osobnosti. Apsolutno je jedan od tih vidova, čiji je također i temelj. Kao što je apsolutno temelj svega onoga što jest, tako je zaokupljenost za apsolutno integracijsko središte osobnog života. Biti bez njega znači biti bez središta «. ${ }^{47}$ Svaki čovjek ima neko središte koje predstavlja temelj projekta njegova života i zbog toga se ne može dopustiti da postoji čovjek koji nema neki vrhovni interes ili krajnju zaokupljenost. Postavlja se pitanje samo što je njegova krajnja zaokupljenost. Takav pristup svakako pomaže u raskrinkavanju ateizma, a osobito agnosticizma, možda bolje nego Balthasarov vid čina vjere.

Ako je vjera iskustvo apsolutnoga i ono što je (u najširem smislu) naša krajnja zaokupljenost, onda moramo pojasniti da zaokupljenost uključuje dvoje: subjekt koji je zaokupljen i objekt kojim je zaokupljen. Oba su pola ključna. Subjektivni čimbenik vjere ovisi o samoj osobi i o mjeri u kojoj je ona sposobna uplesti se u taj proces, ovisi o njezinoj otvorenosti i strasti za krajnju zaokupljenost. Objektiv-

\footnotetext{
${ }^{44}$ T. MANFERDINI, La filosofia della religione in Paul Tillich, Bologna, 1977., 40.

${ }^{45}$ Osobina cijele Tillichove teologije jest da nije biblijska, da se ne poziva na svetopisamske tekstove, a osobito ne na Predaju. Sve je to u izobilju prisutno u Balthasarovu promišljanju o vjeri. Zbog toga su neki teolozi Tillichovu teologiju smatrali heretičnom, nebiblijskom i onom koja se ne podudara s naukom prvih koncila. Usp. G. H. TAVARD, Paul Tillich and the christian message, London, 1962., 131. Šire o tom argumentu vidi: G. OLIANA, Gesù, la domanda, e Cristo la risposta: il metodo della correlazione nella teologia cristomorfica di Paul Tillich, Tione di Trento, 2011., 105-154.

${ }^{46}$ Usp. P. TILLICH, Dinamica della fede, 17-18. Upravo se u tome ogleda sva dinamičnost vjere jer postoji odnos ili jedna beskrajna tenzija između Božje apsolutnosti i čovjekove relativnosti. Usp. isto, $55 \mathrm{~s}$.
}

${ }^{47}$ Usp. isto, 89-90. Kurziv je naš. 
ni čimbenik vjere ovisi o odsutnosti idolatrijskih elemenata u njemu, odnosno u kojoj je mjeri vjera usmjerena prema istinskom, a ne pogrješnom apsolutu. Ako vjera postane idolatrijskom, onda ona vodi prema dezintegraciji osobe i svih njezinih činova, ${ }^{48}$ upravo zbog toga što se osoba izručila nečemu što je samo prividno apsolutno.

Upotreba neodređenih pojmova, koje je moguće razumjeti u najširem smislu, npr. bezuvjetno, beskonačno i apsolutno vode Tillicha do onoga s čime se ne možemo složiti iz naše katoličke perspektive. Naime upotrebom tih pojmova nije nadiđena razlika između fides qua i fides quae. U Tillichovim promišljanjima ono što je bezuvjetno i apsolutno u činu vjere pokazuje se bezuvjetnim i apsolutnim i u sadržaju vjere. Dakle kod Tillicha postoji identifikacija između fides qua i fides quae. Ovdje vidimo upliv subjektivizma koji je posve oprečan Balthasarovoj objektivnoj formi objave, gdje je sadržaj vjere dan objavom. Čini se katkada da Tillich teži tomu da vjeru svede samo na subjektivni vid gdje je važniji način na koji se vjeruje od sadržaja vjere, zaboravljajući tako da nije način vjerovanja ono što utemeljuje nosivu razliku, nego objekt uz koji prianjamo. Naime moramo jasno istaknuti da se prema katoličkom poimanju fides qua ne može identificirati s fides quae jer iskustvo, tj. subjektivna vjera nije neovisna o (doktrinalnome) sadržaju, tj. o objektivnoj vjeri. Subjektivni vid vjere ne može postojati bez objektivnoga vida. To je ono na čemu i Balthasar inzistira. Postoji ontološka povezanost između tih dvaju polova koji proizlaze od Boga i oba pola imaju veliku važnost za spasenje. Kod Tillicha vjera gubi i oznaku dara jer se čini kako je sam čovjek zaslužan za nju.

\subsection{Religija KaO DUbinsKa DimenZiJA}

Kada se govori o religiji, postavlja se pitanje je li ona dimenzija ljudskoga duha (kao volja, inteligencija, moralni i afektivni život) ili je dar objave. Teolozi koji negiraju religiju kao dimenziju ljudskoga duha drže da je ona dar objave. U tom slučaju čovjek ne može stići do Boga, nego se Bog priopćava čovjeku. Prema Tillichu to za posljedicu ima da je ljudski duh kreativan samo u onome što se tiče čovjeka, a ne i u onome što se tiče Boga. S druge strane znanstvenici koji objašnjavaju religiju kao jednu od posebnih osobina ljudskoga razvoja (Comte) vide ju kao konstrukciju ljudskoga duha, a ne kao čovjekovu esencijalnu kvalitetu. Teolozi i znanstvenici razumiju religiju kao odnos s božanskim bićima. Prema Tillichu, upravo je tu problem jer tako shvaćena religija, iako ne dokida relacionalnost, poima Boga kao objekt pored drugih objekata o čijoj se egzistenciji može raspravljati. ${ }^{49}$ Stoga Tillich

\footnotetext{
${ }^{48}$ Usp. isto, 92.

${ }^{49}$ Usp. P. TILLICH, Teologija kulture, 11s. Na jednak problem upućuje i kardinal Müller. Usp. G. L. MÜLLER, Razgovor o nadi. Razgovor s Carlosom Granadosom, Split, 2016., 29s.
} 
religiju radije razumije kao dubinsku ili najdublju dimenziju ljudskoga duha. Upravo je ta dimenzija ljudskoga duha izvorno mjesto susreta Boga s čovjekom i njegovim svijetom. Po svojoj naravi čovjek je homo religiosus. Religija je stvarna dimenzija ljudskoga duha i uvijek je prisutna, tako da religija nije neka nadstruktura, nego ima najdublje korijene u ljudskome duhu. ${ }^{50}$

Opisati religiju kao dimenziju, vid ili aspekt ljudskoga duha po sebi znači da je ljudski duh religiozan. Tillich još jasnije izražava to uvjerenje podcrtavajući da $\gg$ religija nije neka posebna funkcija ljudskoga duha, nego dubinska dimenzija svih funkcija $\ll^{51}$. To da je religija dubinska dimenzija znači da, slikovito rečeno, religija u potrazi za vlastitim prebivalištem od jedne do druge funkcije ljudskoga duha ne uspijeva pronaći vlastito prebivalište, ona postaje odbačena u svakoj drugoj funkciji i ne pronalazi odgovarajuće mjesto ni u moralu, ni u estetici, ni u afektivnoj, ni u spoznajnoj funkciji. Na kraju, iskušavajući sve te funkcije, religija spoznaje da nema potrebu za vlastitim mjestom jer je ona svugdje doma, dapače, u dubini svih funkcija ljudskoga duha i djelotvorna je u svakoj od njih.

To da je religija dubinska dimenzija označava ponajprije da religija u svim funkcijama ljudskoga duha usmjerava ljudsku egzistenciju prema nečemu krajnjem i bezuvjetnom i svim funkcijama ljudskoga duha daje terminus ad quem. Religija to može činiti jer je utemeljena na objavi koja joj udjeljuje tu dubinu. Ni ekonomija, ni kultura, ni politika, ni umjetnost nisu elementi utemeljeni na objavi i zbog toga nemaju dubinu koja je udijeljena religiji. Krajnja zaokupljenost postoji u svim kreativnim funkcijama ljudskoga duha: u moralu, estetici, spoznaji, afektivnom životu. Religija je, kao stanje onoga tko je zahvaćen krajnjom zbiljnošću, temelj, supstancija i dubina ljudskoga duha te ju se zbog toga ne može odbaciti s ozbiljnošću. ${ }^{52}$

Religija je kao iskustvo bezuvjetnoga ono što udjeljuje smisao i značenje svakoj stvarnosti, ali ne pored ili onkraj ograničene stvarnosti, nego preko nje, kao njezina unutarnja značenjska kvalifikacija. ${ }^{53}$

\footnotetext{
${ }^{50}$ Usp. P. TILLICH, Teologija kulture, 11. Za razliku od Barthova biblijskoga fideizma koji isključuje iz vjere sve ljudsko, razumijevajući vjeru kao ekskluzivno Božje djelo, Tillich ne apstrahira od ljudskoga elementa u vjeri. On ističe da vjera nije moguća bez čovjekova sudjelovanja jer je čovjek jedini subjekt vjere i upravo to od vjere čini ljudsku (antropološku) mogućnost. (Usp. P. TILLICH, Dinamica della fede, 15.) Kako bi naglasio ljudski element u vjeri, Tillich tvrdi da se mora uzeti u obzir da se sve religije temelje na nečemu što je dano čovjeku na kojem god mjestu živio. Čovjek je primatelj objave, ali ju je primio u ljudskom ograničenom stanju koje uključuje prihvaćanje objave u jednom iskrivljenom obliku. Usp. P. TILLICH, Il futoro delle religioni, Brescia, 1970., 118-119.

${ }^{51}$ P. TILLICH, Teologija kulture, 13.

${ }^{52}$ Usp. isto, 14-15.

${ }^{53}$ Usp. T. MANFERDINI, La filosofia della religione in Paul Tillich, 94.
} 


\subsection{IZGUBLJENA DIMENZIJA?}

Kao iskustvo bezuvjetnoga, krajnjega i apsolutnoga religija mora biti u stanju nadići sve ono što je svakodnevno i provizorno. Ako ne uspije u tome, ne vrijedi je slušati. Ako religija nema riječ za naše vrijeme, za našu situaciju, onda nije dostojna pozornosti. Ona ima vlastitu vrijednost samo ako nadilazi, sudi i preobražava našu situaciju. Na temelju toga možemo reći da je vjera/religija duhovni mač sposoban suditi, preobraziti i nadići svaki entuzijazam i svaku ljudsku sigurnost.

Za Tillicha je važnost religije za čovjeka i društvo u cjelini neupitno, osobito u suvremenoj kulturi u kojoj je gotovo posve zaboravljena vertikalna dimenzija, dok se $\mathrm{u}$ isto vrijeme horizontalna dimenzija uzvisuje kao jedina, zaboravljajući da je čovjekovo ostvarenje isključivo na horizontalnoj liniji posve fragmentarno. Razlog zaborava vertikalne dimenzije, prema Tillichu, sastoji se u prevlasti aktivnoga života nad kontemplativnim. Aktivni život koji oblikuje svijet zaboravlja kontemplativnu dimenziju i nosi sa sobom zanimanje za tehničke znanosti koje postaju dominante u interpretaciji svijeta, gdje telos (rezultat, svrha, cilj) postaje jedina svrha ljudske egzistencije. ${ }^{54} \mathrm{U}$ takvoj situaciji čovjek mora pronaći religijsku dimenziju koja će mu ponuditi ono onkraj, ono vječno. Kritičko pitanje koje Tillich postavlja jest je li religijska supstancija još uvijek živa u društvu ili je iščeznula i jesu li crkve i religijske zajednice spremne i kadre pokazati tu religijsku supstanciju ili nisu?

Kako bi odgovorio na to pitanje, Tillich objašnjava kako su naša kultura i naš stil života karakterizirani duhom industrijskom društva i otporom prema takvomu pokretu. Dvije su karakteristike čovjeka u industrijskom društvu od kojega vuče korijen i naše današnje društvo. Prvo, postalo je očito da se čovjek posve posvetio tehničkoj preobrazbi svijeta, podrazumijevajući preobrazbu samoga čovjeka. Kao posljedica takve preobrazbe opaža se gubitak dubinske dimenzije u susretu sa stvarnošću. Stvarnost koju čovjek producira lišena je transcendentnosti, zbog čega čovjeku izmiče konačni cilj. Bog je posve izbačen iz polja ljudske aktivnosti jer u takvome društvu Bog ometa čovjekove planove. U krajnjoj liniji, osobina industrijskoga društva sastoji se u činjenici da je Bog postao suvišan, a čovjek je postao gospodar svemira. ${ }^{55}$

Drugo obilježje industrijskoga društva potječe od činjenice da kada je Bog istjeran iz društva, čovjek pripisuje samome sebi one djelatnosti koje pripadaju Bogu, po-

\footnotetext{
${ }^{54}$ P. TILLICH, Il futuro delle religioni, 148-149. Prema I. Sanni u postmoderni, iščeznućem vertikalne transcedencije, $\mathrm{u}$ jednini, pojavile su se horizontalne transcedencije, u množini. One proizvode nastanak političkih mistika ili nastoje pobožanstveniti prirodnu stvarnost. Te horizontalne transcendencije stoje same, bez vertikalne oslonjenosti. Usp. I. SANNA, L'antropologia cristiana tra modernità e postmodernità, Brescia, ${ }^{4} 2012$., 324-329.

${ }^{55}$ Usp. P. TILLICH, Teologija kulture, 42.
} 
drazumijevajući apsolutnu stvarateljsku moć. Riječ je o srazu onoga što je čovjek esencijalno i onoga što u stvarnosti postaje. Čovjek zaboravlja na stanje svoje otuđenosti ili, rečeno biblijskim rječnikom, biva zanemareno stanje pada ${ }^{56}$ (ako ne i zanijekano). Čovjek industrijskoga društva ne govori više o smrti i grijehu jer bi mu to zapriječilo da sebi podloži svijet koji stvara. Čovjek i danas osjeća nedostatke, ali oni nisu izraženi u pojmovima grijeha koji posve iščezava iz ovoga društva. Svemir je zauzeo mjesto Boga, a čovjek mjesto Krista. U takvome društvu ne prepoznaje se više dubinska dimenzija, ona je iščeznula i rezultat toga očit je u svim kulturnim kreacijama industrijskoga društva, ${ }^{57}$ pa i ovoga našega danas.

U takvome ozračju postavlja se pitanje o kraju religije. Je li religija posve iščeznula? Odgovor na to pitanje možemo dati ponukani Tillichovim promišljanjima u kojima on jasno ističe da ako religija postane saveznica javnoga mišljenja i ponavlja ono što svi govore, tada ona gubi vlastito dostojanstvo i postaje beskorisna, postaje dimenzija pored svih drugih dimenzija i otapa se u dominantnoj kulturi. Religija mora izbjeći opasnost preobrazbe iz mesijanske religije (obraćenje, ljubav, spremnost na patnju i nasljedovanje) u građansku religiju (stavlja u prvi plan posjedovanje i uspjeh). Religija ne može potvrđivati nepravedni građanski poredak, nego ga prekinuti u smislu da posljednji dolaze na mjesto prvih, a na mjesto zakona zakon ljubavi. ${ }^{58}$ Takva preobrazba uključuje metanoju, obraćenje, radikalnu promjenu stava. Ako želi imati svoju budućnost, religija mora nadići sve utopije koje nude razne ideologije te mora biti oprezna da ne padne u opasnost da posveti različite situacije ljudske egzistencije bez da ih prosuđuje, preobražava i nadilazi. Uloga religije koja želi imati svoju budućnost sastoji se u tome da kaže ljudima one riječi koje ne mogu čuti na drugim mjestima. To je, prije svega, riječ nade, a ne ponavljanje onoga što se može čuti na radiju i televiziji. Religija mora podići svoj glas jer ona zna ponešto o povijesti i o čovjeku i poznaje tragediju i nadu vremenskoga jer poznaje ono vječno i zbog toga može i mora, jer je dubinska dimenzija, opskrbiti posljednji temelj i posljednje kriterije egzistencijalnih i društvenih odluka. ${ }^{59}$ Takav pristup i opis religije otkriva nadasve njezinu egzistencijalnu dimenziju. Kao takva ona ne smije biti eliminirana, nego se pojavljuje kao nužna dimenzija ljudske egzistencije.

\footnotetext{
${ }^{56}$ Usp. isto, 43.

${ }^{57}$ Usp. P. TILLICH, L'era protestante, 216.

${ }^{58}$ Usp. J. B. METZ, Al di là della religione borghese. Discorsi sul futuro del cristianesimo, Brescia, ${ }^{2} 1990$. , 8.

${ }^{59}$ Usp. P. TILLICH, L'era protestante, 218-219.
} 


\section{Zaključna zapažanja}

Iako nam nije cilj prispjeti konvergentnim i divergentnim točkama u teološkim promišljanjima o vjeri kod Balthasara i Tillicha, ipak nam se čini shodnim u zaključku istaknuti nekoliko važnih zapažanja. Riječ je o različitim kutovima gledanja na vjeru, ali svi ti kutovi nam zapravo otkivaju bogatstvo i neiscrpnost vjere.

Vjera u Balthasarovim promišljanjima ima jasan kristološki temelj, dok je vjera u Tillichovim promišljanjima prilično široko shvaćena, bez primisli na eksplicitnu kristološku središnjost. Kod njega je vjera iskustvo apsolutnoga tako da možda tek u nekoj konačnoj fazi možemo misliti vjeru kristološki. Kod Balthasara je to odmah očito, kristološki moment jest polazište ako je vjera u opažanju, a kasnije i u prianjanju uz Gestalt, formu koja se u svojoj povijesnoj dimenziji očituje u Isusu Kristu, kao objavljenoj i konačnoj Božjoj Riječi.

Temeljno Balthasarovo polazište jest da subjektivna iskustvena sposobnost ne može biti shvaćena i osvijetljena bez konkretnoga objekta koji ima svoju formu (Gestalt). U Tillichovoj teologiji vjere, s Balthasarove točke gledišta, postaje krajnje problematično to što ne postoji konkretnost bilo kakve forme, a osobito kristološke. Ako ćemo još radikalnije to izreći, onda moramo reći kako je u Tillicha problem kako uopće doći do konkretnoga objekta. Kod Balthasara je jasno da onaj tko je susreo svjetlo ne može ga ne prepoznati. Za Tillicha je objekt objave erupcija bezuvjetnoga u njegovoj bezuvjetnosti što dovodi do pitanja gdje je onda to bezuvjetno posvjedočeno. Tillich izbjegava naznačiti konkretni objekt objave, izbjegava čak i samu riječ Bog, te više stavlja naglasak na religiozno iskustvo i na kvalitetu, kao i na način na koji se ima iskustvo zajedničke stvarnosti. ${ }^{60}$

Protiv Tillichove ne-forme objave Balthasar nudi tri razloga zašto objava Boga mora imati objektivnu formu. Prvo, Bog uvijek ostaje interior intimo meo, transcendentan i misterij u svojoj objavi. No i najintimnije priopćavanje Boga posjeduje formu, iako duhovnu; kroz iskustva, osjećaje, prosvjetljenje. Drugo, Bog se najprije objavio kao Stvoritelj. Stvaranje je očitovanje Boga. To znači da stvaranje ima svoju formu u samoj formi svijeta. Božanstvo nevidljivoga koje se isijava u vidliivosti bića svijeta naziva se slava Boga (doksa). Objava po stvaranju jest $\mathrm{u}$ funkciji priprave objave $\mathrm{u}$ Kristu. Treće, forma objave u Kristu karakterizirana je kao ispunjenje forme svijeta. Ona je to samo kada se u vjeri vidi kao očitovanje trojedinoga Boga. Samo u Kristovu božanstvu očituje se intimna i vlastita forma kršćanske objave. ${ }^{61}$

\footnotetext{
${ }^{60}$ Usp. T. MANFERDINI, La filosofia della religione in Paul Tillich, 76.

${ }^{61}$ Usp. H. U. von BALTHASAR, Gloria, I, 399-403.
} 
Balthasar ovdje ukazuje na to da se pojmom forme moramo koristiti razborito te izbjegavati apstraktni i univerzalni sadržaj toga koncepta. Zato Balthasar nedvosmisleno tvrdi da se samo u Kristovu božanstvu očituje intimna i vlastita forma kršćanske objave. ${ }^{62}$ Čini nam se da upravo to Tillich nije uspio izbjeći, ako bismo željeli reći da pojmovi konačno, bezuvjetno i apsolutno kod Tillicha označavaju barem približno ono što Balthasar izražava pojmovima Gelstalt, doksa, pulchrum. Moramo naglasiti da Tillich svomu pojmovlju pridaje, ipak, previše apstraktan i univerzalan sadržaj. Balthasar s pravom ukazuje da postoje vremena u kojima se zbog predstavljanja mnoštva formi može upasti u napast i skrenuti od iskonske forme u one koje su sekundarne i samoproizlazeće i u kojima je vrlo teško pronaći iskonsku formu jer se pogled ne usmjerava na formu zbog toga što smo naviknuli čitati stvarnost polazeći odozdo prema gore, a ne od cjeline prema dijelu. ${ }^{63}$ I ovdje možemo čitati oštru kritiku subjektivizmu i antropološkom poimanju vjere koju upućuje Balthasar.

Za razliku od Balthasara, Tillich u svojim promišljanjima o vjeri ima potrebu pripremiti teren, zato govori o važnosti situacije u kojoj se nalazi suvremeni čovjek kao naslovnik objave, kao onaj koji vjeruje, te o misteriju našega čovještva koje je mjesto prisutnosti onoga čime smo krajnje zaokupljeni. Onoliko koliko je Tillich zanemario važnost forme objave, u sličnoj mjeri je i Balthasar zanemario važnost situacije u kojoj se nalaze naslovnici objave koji opažaju Gestalt i uz njega prianjaju.

Balthasar vidi vjeru kao participaciju na božanskoj samospoznaji i na trojstvenoj ljubavi. Takva impostacija teologije vjere u Balthasara riskira udaljavanje od jezika onoga koji jednostavno traži Boga. S dijaloške točke gledišta Tillichovo poimanje vjere koje je više antropološko i koje polazi odozdo na mnogo primjereniji način može zaintrigirati one koji ne vjeruju. Poimanje vjere koje nam donosi Balthasar lakše je razumljivo za one koji već vjeruju ili, bolje reći, za one koji imaju solidno teološko i vjersko znanje. Golem Balthasarov doprinos sastoji se u tome što nas je, u modernoj misli u kojoj je dominantna uloga subjekta i gdje se riskira da subjekt postane jedini smjer, usmjerio na objekt. Osobito u postmoderni počeli smo živjeti tako da subjektivni vid vjere posve prevladava nad objektivnim. Stavljanje naglaska

\footnotetext{
${ }^{62}$ Usp. isto, 399-403. Osobina Boga koji se pokazuje neshvatliivim u svojoj objavi pripada objektivnoj očiglednosti same objave, a ne zatamnjenosti zemaljske vjere. Prema Balthasaru, ta osobina ostat će i kod gledanja Boga licem u lice jer bila bi teška uvreda Bogu kada bi se visio facialis željelo interpretirati kao comprhensio u smislu znanosti i filozofije. Aksiom si comprehendis non est Deus vrijedi na nebu kao i na zemlji, samo s promjenom iz spes u res. Upravo to označava vidjeti Boga sicut est. Ako glede visio facialis nije kontradiktorno reći da ćemo tada vidjeti neshvatljivoga Boga unutar svake shvatljivosti, onda, gledajući iz nebeske perspektive vjere prema zemaljskoj vjeri, nije kontradiktorno reći da je vjera na svoj način gledanje i razumijevanje misterija bez da misterij bude lišen svoga misterija. Usp. isto, 432.
}

${ }^{63}$ Usp. isto, 16 s. 
na objektivnost poziva nas da ponovno napravimo prostora u odnosu s Bogom, poziva nas na klanjanje, na poslušnosti i pobožnost spuštajući naočale subjektivizma. Jezik vjere u Balthasara podsjeća nas da je Božja slava mnogo veća od svakoga mogućega našega odgovora Bogu. Slava koja odsijeva na Kristovu licu poziv je na puninu ljudskosti, ali ide onkraj punine mjerene mjerom subjekta jer je ta slava sjaj Raspetoga Isusa kao Uskrsnuloga Gospodina.

Različiti kutovi gledanja na vjeru ne smiju nipošto biti ekskluzivistički (isključujući), nego nam pružaju mogućnost da to $\gg$ blago u glinenim posudama « $(2 \operatorname{Kor} 4,7)$ što pozornije promotrimo i njegujemo. Zahvaljujući upravo različitim pristupima vjeri, otkriva nam se bogatstvo same vjere u svoj njezinoj složenosti, praćena sjajem i tamom u isto vrijeme. »Neovisno o putu kojim idemo prema vjeri krucijalno je ne izgubiti iz vida vrh kojemu nastojimo stići. $\ll{ }^{64}$

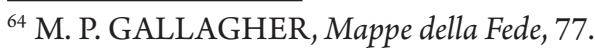




\title{
ON SOME ASPECTS OF UNDERSTANDING FAITH IN HANS URS VON BALTHASAR AND PAUL TILLICH
}

\author{
Hrvoje KALEM*
}

Summary: The question of faith can be approached under many aspects, but one thing is certain: in all these aspects faith is what touches our existence. Regardless of the path we take towards faith, it is crucial not to lose sight of the peak we are trying to reach. The article aims to point to two different approaches to the concept of faith that have their advantages and disadvantages. In the first part, the article discusses the thoughts on faith of the great Swiss Catholic theologian Hans Urs von Balthasar whose starting point is the belief that the object of revelation we adhere to must have a concrete form (Gestalt). Further analysis brings some basic aspects of understanding faith in the theologian's thoughts. The second part discusses the understanding of the faith/religion of the German-American Protestant theologian Paul Tillich. His methodological approach to understanding faith is completely contradictory to Balthasar's, but it also reveals some advantages, like emphasizing the importance of the situation in which the recipients of Christian message adhere to God's revelation, as well as the very methodological approach to understanding faith which is more receptive for those who lack certain religious and theological knowledge and who are simply in search of God, as indicated by concluding remarks.

Keywords: Balthasar, Tillich, faith/religion, Gestalt, testimony, the center and object of faith, experience, situation, absolute, ultimate concern.

\footnotetext{
* Hrvoje Kalem, Ph. D., Catholic Faculty of Theology in Đakovo, J. J. Strossmayer University of Osijek, P. Preradovića 17, 31400 Đakovo, Croatia, hrvojekalem@gmail.com
} 